4 Rybo G, Westerberg H. Symptoms in the postmenopause-a population study. A preliminary report. Acta Obstet Gynecol Scand 1971 ;suppl 9: 25.

5 Campbell S. Intensive steroid and protein hormone profiles in postmenopausal women experiencing hot flushes and a group of controls. In: Campbell S, ed. The management of the menopause and postmenopausal years. Lancaster: MTP Press Limited, 1976:63-77.

- Schiff I, Ryan KJ. Benefits of estrogen replacement. Obstet Gynecol Surv $1980 ; 35: 400-11$.

7 Lindsay R, Hart DM, Aitken JM, MacDonald EB, Anderson JB, Clarke AC. Long-term prevention of postmenopausal osteoporosis by oestrogen. Evidence for an increased bone mass after delayed onset of oestrogen treatment. Lancet 1976; : $1038-40,1$.

8 Hunter DJS, Akande EO, Carr P, Stallworthy J. The clinical and endocrinological effect of oestradiol implants at the time of hysterectomy and bilateral salpingo-oophorectomy. Fournal of Obstetrics and Gynaecology of the British Commonwealth 1973;80:827-33.

- Thompson B, Hart SA, Durno D. Menopausal age and symptomatology in a general practice. $\mathcal{F}$ Biosoc $S_{c i} 1973 ; 5: 71-82$.

10 Whitehead MI, Townsend PT, Pryse-Davies J, et al. Effects of various types and dosages of progestogens on the postmenopausal endometrium. f Reprod Med 1982;27:539-48.

11 Thom MH, White PJ, Williams RM, et al. Prevention and treatment of endometrial disease in climacteric women receiving oestrogen therapy. Lancet 1979 ;ii:455-7.

12 Dixon A StJ. Non-hormonal treatment of osteoporosis. $\mathrm{Br} \mathrm{Med} \mathcal{F} 1983$; 286 :999-1000.

${ }^{13}$ Nordin BEC, Horsman A, Crilly RG, Marshall DH, Simpson M. Treatment of spinal osteoporosis in postmenopausal women. Br Med $\mathcal{f} 1980$; 280:451-4.

14 Utian WH. The mental tonic effect of oestrogens administered to oophorectomized females. $S$ Afr Med $\mathcal{F} 1972 ; 46: 1079-82$.

\section{Reflux nephropathy}

One of the many contributions which Hodson has made in reflux nephropathy has been the organisation of two small multidisciplinary international workshops, the first held in Bermuda in $1978^{1}$ and the second sponsored by the Kroc Foundation in the Santa Ynez Valley in California in October 1982. This four year period has seen some important advances in our knowledge of this renal disease, which ranks second only to glomerulonephritis as a cause of end stage renal failure ${ }^{2}{ }^{3}$ and is the most common cause of severe hypertension in childhood. ${ }^{4}$

Radionuclide methods are now widely used in the assessment of reflux nephropathy, and at the workshop $M J$ Dillon showed how parenchymal scars could be located accurately with ${ }^{99 \mathrm{~m}}$ Tc labelled dimercaptosuccinic acid (DMSA); he had found high renin concentrations in segmental renal veins draining scarred areas detected on these scans. The concept that scars in kidneys affected by chronic atrophic pyelonephritis or reflux nephropathy are ischaemic and might produce renin is not new, ${ }^{5}$ but Dillon's recent data are by far the most convincing evidence that scarred areas of this origin produce renin. He also reported that eight of 10 children with high concentrations of renin in the renal vein from a unilateral scarred kidney and three of six children with bilateral segmental scars were cured of their hypertension by surgical removal of the scarred areas. In general improved drug treatment reduced the need for such surgical excision. The young child with severe refractory hypertension, however, presents a special problem and surgery may achieve remarkable results.

One of the most reassuring papers was given by Kate Verrier-Jones, of Cardiff, who reported on long term follow up of renal function in children with vesicoureteric reflux detected during the Oxford-Cardiff bacteriuria study, based on screening 14000 asymptomatic schoolgirls. ${ }^{6}$ The function of individual kidneys was measured by ${ }^{99 \mathrm{~m}} \mathrm{Tc}$ labelled diethylenetriaminepenta-acetic acid (DTPA); the scarred kidneys had a mean glomerular filtration rate of $30 \mathrm{ml} /$ minute compared with $62 \mathrm{ml} /$ minute for unscarred kidneys. There was, however, no difference between kidneys with and without reflux whether they were scarred or not. The girls attended at three monthly intervals for urine culture, but they showed poor compliance with treatment, which was prescribed only in short courses for those with infection. The actual rate of infected urine specimens was quite high; no decline in the glomerular filtration rate of individual kidneys could be found as the result of urinary tract infection in either scarred or non-scarred kidneys. The total glomerular filtration rate was the same in 21 patients in the original control group and 27 in the original treated group.

The results of this study have done much to alleviate the concern which we all may have about the impact of vesicoureteric reflux on the renal parenchyma when it continues through childhood and persists in the adolescent and adult. Some previous radiological studies have painted a much more worrying picture of increasing scar formation with age, ${ }^{7}{ }^{8}$ but Verrier-Jones's results lend some support to Jean Smellie's view of the benign course of reflux nephropathy in girls over 5 years old who are under medical supervision. Normand and Smellie advocate continuous chemotherapy and close follow up, ${ }^{9}$ but in the Cardiff study function did not decline despite short courses of treatment and poor compliance. N Goldraich from Brazil reported on reflux nephropathy in a large paediatric service and, like Verrier-Jones, could not find progressive impairment of function after the age of 5 in children whose acute incidents were treated with antibiotics.

Though these results are reassuring to those who advocate conservative management of reflux nephropathy in childhood, we must not lose sight of the need to identify the group who end up having dialysis. The proportion of patients with reflux nephropathy who develop end stage renal failure cannot easily be calculated because in general only patients with symptoms are studied. Follow up of these detected by screening for bacteriuria (without symptoms) has produced little evidence of progression. Screening studies suggest that $0 \cdot 5-1.0 \%$ of women have reflux nephropathy. ${ }^{10} 11$ The highest estimates suggest that no more than $5-10$ women per million of the population present yearly with end stage renal failure from this cause, so that probably only one woman in every 1000 with reflux nephropathy is at risk of progressing to end stage renal failure. Men who develop end stage renal failure do so at an early age (mean 22), whereas women require dialysis a decade later (mean age 33). The rate of progression may be accelerated by pregnancy. Four patients with impaired renal function in early pregnancy deteriorated rapidly requiring dialysis within a few months of delivery, in contrast to the usual slowly progressive course over 7-10 years.

Proteinuria, which reflects an underlying glomerular lesion, is the most important prognostic feature. All those whose disease progresses have proteinuria, and those with proteinuria exceeding 1 gram in 24 hours show a progressive decline in renal function. The suggestion first made 10 years ago that the development of a glomerular lesion in non-scarred parenchyma might cause progression in reflux nephropathy ${ }^{2} 12$ arose from finding a progressive course in adults with unilateral scarring. Three more examples of progressive decline in function in women with unilateral scarred kidneys were presented at Santa Ynez. In one, the hypertrophied contralateral kidney measured $16 \mathrm{~cm}$ in length. The importance of a progressive glomerular lesion has been well documented by others ${ }^{13} 14$ but the reason that it develops is uncertain. Some strongly favour the view that it is due to hyperperfusion..$^{15}$ If hyperperfusion of glomeruli in a normal sized or hypertrophied kidney in 
reflux nephropathy can result in a progressive decline in function this has worrying implications for living kidney donors.

Everyone has been waiting for the results of controlled trials comparing surgical correction with conservative management of vesicouretic reflux. The preliminary results suggest that there is no compelling case for surgical correction. The Birmingham study set up in 1975 includes 149 children under the age of 15 with newly diagnosed vesicouretic reflux (grade II with scarring and grade III with or without scarring). Children were allocated at random either to surgical correction of vesicouretic reflux or to conservative management. Both groups received continuous prophylactic chemotherapy. Analysis of the results in 49 surgically treated (69 ureters) and 47 conservatively treated children (66 ureters) showed no essential differences. Progression of radiographic scarring as shown by Ecklöf's measurements ${ }^{16}$ was recorded in seven of those treated surgically and in 11 of the controls. No significant difference was seen in renal length in the two groups, and new scars appeared in two patients in each group (two over the age of 5 and two with no documented urinary tract infection). Renal function evaluated by edetic acid (EDTA) glomerular filtration rates showed no difference between the groups, but in those aged over 6 there was a difference in concentrating capacity. The rate of "breakthrough" urinary tract infection did not differ in the two groups, but the kidneys of the 28 who developed urinary tract infections grew less than the others.

P G Ransley reported on the important trial of surgery in infants under the age of 1 year with gross vesicouretic reflux which has been conducted at the Hospital for Sick Children in London over the past five years. There are 12 patients in the conservative group and 11 in whom vesicouretic reflux has been repaired surgically. Three of the latter still show vesicouretic reflux; thus, even in the best hands, surgery in infants is not always successful. Five year follow up in seven in the conservatively managed group and six in the treated group showed no difference in glomerular filtration rate estimated by EDTA labelled with ${ }^{51} \mathrm{Cr}$.

\section{PRISCILla KINCAID-SMITH}

Professor of Medicine,

University of Melbourne, and

Director of Nephrology,

Royal Melbourne Hospital,

Victoria 3050,

Australia

${ }^{1}$ Hodson J, Kincaid-Smith P, eds. Reflux nephropathy. New York: Masson Publishing, 1979.

2 Kincaid-Smith P. The prevention of renal failure. In: Villarreal $\mathbf{H}$, ed. Proceedings of the fifth international congress on nephrology. Clinic. Vol 3. Basle: $S$ Karger, 1974:110-8.

3 Jacobs C, Broyer M, Brunner FP, et al. Combined report on regular dialysis and transplantation in Europe, XI, 1980. Proc Eur Dial Transplant Assoc 1981;18:4-58.

4 Still JL, Cottom D. Severe hypertension in childhood. Arch Dis Child 1967;42:34-9.

${ }^{5}$ Kincaid-Smith P. Vascular obstruction in chronic pyelonephritic kidneys and its relation to hypertension. Lancet 1955 ;ii:1263-9.

- Cardiff/Oxford Bacteriuria Study Group. Sequelae of covert bacteriuria in schoolgirls. A four-year follow-up study. Lancet 1978;i :889-93.

7 Lenaghan D, Whitaker JG, Jensen F, Stephens FD. The natural history of reflux and long-term effects of reflux on the kidney. $\mathcal{F}$ Urol 1976;115: 728-30.

${ }^{8}$ Filly R, Friedland GW, Govan DE, Fair WR. Development and progression of clubbing and scarring in children with recurrent urinary tract infections. Radiology $1974 ; 113: 145-53$.

- Normand C, Smellie J. Vesicoureteric reflux: the case of conservative management. In : Hodson JC, Kincaid-Smith P, eds. Reflux nephropathy. New York: Masson Publishing, 1979:281-6.

${ }^{10}$ Kincaid-Smith P, Bullen M. Bacteriuria in pregnancy. Lancet $1965 ; \mathrm{i}$ : 395-9.

${ }^{11}$ Alwall N. Screening for urinary tract infection in nonpregnant women. Kidney Int 1975;8, suppl 4:S107-12.

12 Kincaid-Smith P. Discussion-classification of glomerulonephritis. In : Kincaid-Smith P, Mathew TH, Becker EL, eds. Glomerulonephritis. Chichester: John Wiley and Sons, 1973:155-61.

13 Torres VE, Velosa JA, Holley KE, Kelalis PP, Stickler GB, Kurtz SB. The progression of vesicoureteral reflux nephropathy. Ann Intern Med 1980; 92:776-84.

14 Bhathena DB, Weiss JH, Holland NH, et al. Focal and segmental glomerular sclerosis in reflux nephropathy. Am $\mathcal{f}$ Med $1980 ; 68: 886-92$.

${ }^{15}$ Cotran RS. Glomerulosclerosis in reflux nephropathy. Kidney Int 1982; 21 :528-34.

${ }^{16}$ Eklöf $\mathrm{O}$, Ringertz $\mathrm{H}$. Kidney size in children. A method of assessment. Acta Radiol (Diagn) 1976;17:617-25.

\section{Regular Review}

\section{Fraud in science}

\section{LARRY ALTMAN， LAURIE MELCHER}

Two cardinal rules of biomedical research are that scientists pursue absolute truthfulness and objectivity and that they report only honest data. Yet in recent years there has been evidence that these rules have been broken, as admirably summarised in Hamblin's review in the Christmas BMF of $1981 .{ }^{1}$ Of the three main types of malpractice, perhaps the most dramatic is simple plagiarism, as exemplified by $\mathrm{Dr}$ Elias Alsabti, a Jordanian who spent time in postgraduate training in the United States, who simply copied over 60 articles, publishing them under his own name in Japanese and European journals. ${ }^{2}$ Second comes plagiarism together with forgery of data. For example, Dr Vijay Soman, a research associate working with Dr Philip Felig at Yale, copied part of the text of an article sent to his chief to referee and added some imaginary data. ${ }^{13}$ The discovery led to the finding of more papers with data fudged, faked, or missing written by Soman and to the resignation of Dr Felig from his recent appointment to the chair of medicine at Columbia. The final type of fake is concocting false data, as in the case of Dr John Darsee, a research worker in Dr Eugene Braunwald's department at Harvard Medical School, who forged haemodynamic data in a study of the action of drugs on dog myocardium. ${ }^{4}$

Such instances, and others, raise several questions that need answering. Are the cases of piracy-plagiarism-forgery 